\title{
KEANEKARAGAMAN GENETIK KARANG LUNAK Sarcophyton trocheliophorum PADA POPULASI LAUT JAWA. NUSA TENGGARA DAN SULAWESI
}

\author{
Oleh \\ Aradea Bujana Kusuma ${ }^{1^{*}}$, Dietrich Geoffrey Bengen ${ }^{2}$, Hawis Madduppa $^{2}$, \\ Beginer Subhan ${ }^{2}$ dan Dondy Arafat ${ }^{2}$ \\ ${ }^{1}$ Program Studi Ilmu Kelautan, Universitas Bengkulu \\ ${ }^{2}$ Departemen IImu dan Teknologi Kelautan, Institut Pertanian Bogor \\ `Email: aradea.bujana@gmail.com \\ Received February 2016, Accepted March 2016
}

\begin{abstract}
ABSTRAK
Genetik menjadi kunci konservasi karena berperan penting dalam mempertahankan dan memulihkan populasi dari kerusakan. Kerusakan pada ekosistem terumbu karang dapat menjadi pemicu kepunahan organisme laut. Salah satu organisme yang tidak terhindar dari kerusakan tersebut ialah Sarcophyton trocheliophorum. Kerusakan tersebut dapat menyebabkan menurunnya keragaman genetik $S$. trocheliophorum. Tujuan dari penelitian ini adalah menganalisis keanekaragaman genetik dari $S$. trocheliophorum yang terdapat pada tiga populasi di Perairan Jawa, Sulawesi dan Nusa Tenggara serta mendeskripsikan implikasinya terhadap kawasan konservasi di Indonesia. Penelitian ini menggunakan penanda genetik ND2 untuk menganalisis struktur populasi, konektivitas, dan keragaman genetik. Keragaman genetik $S$. trocheliophorum pada Perairan Jawa, Sulawesi, Nusa Tenggara masing-masing 0.600, 0.815, dan 0.972. Keragaman genetik pada populasi Perairan Jawa lebih kecil dibandingkan pada Populasi Perairan Sulawesi dan Nusa Tenggara. Hal ini dimungkinkan karena banyaknya aktivitas manusia pada pesisir utara Laut Jawa, sehingga berdampak pada menurunnya ukuran populasi $S$. trocheliophorum. Oleh karena itu perlu adanya perlindungan yang ketat pada populasi Jawa untuk menjaga kelestarian keanekaragaman hayati Indonesia.
\end{abstract}

kata kunci: Keragaman genetik, karang lunak, konservasi, Sarcophyton trocheliophorum.

\begin{abstract}
Genetic is the key of conservation to defend its self from damage and overexploitation. Overexploitation of targeted species could lead to marine biodiversity extinction. Sarcophyton trocheliophorum is one of marine ornamental coral which frayed and exploited in Indonesia. Exploitation could decrease genetic diversity in some population. The research aimed to analize genetic diversity of $S$. trocheliophorum in three population of waters Java, Nusa Tenggara, and Sulawesi. We used genetic marker ND2 used to analize genetic diversity. Genetic diversity in Java, Sulawesi, Nusa Tenggara population were $0.600,0.815$, and 0.972 , respectively. Genetic diversity in Java population is smallest than Sulawesi and Nusa Tenggara. It might be caused by human activity in Java coasts and impacted on decrease of their unit population, therefore Java population need to be protected.
\end{abstract}

Key words: Genetic diversity, softcoral, concervation, sarcophyton trocheliophorum 


\section{PENDAHULUAN}

Indonesia merupakan pusat keanekaragaman hayati laut di dunia. Jarak pulau yang saling berdekatan berperan sebagai "stepping stone" untuk mempermudah penyebaran larva karang. Selain itu, pola arus yang kuat di Indonesia juga membantu penyebaran larva. Menurut Benayahu dan Loya (1986) arus merupakan alat bantu yang sangat penting dalam distribusi larva hewan sessil.

Karang lunak Sarcophyton trocheliophorum merupakan salah satu anggota penyusun komunitas karang yang penyebaran larvanya tergantung oleh arus (Benayahu dan Loya, 1986). Walaupun tubuh karang ini lunak, organisme ini memiliki penyokong berukuran kecil yang terbuat dari kalsium karbonat (spikula atau sklerit) yang tersusun di seluruh tubuh, sehingga tubuh karang ini lentur dan tidak mudah putus (Manuputty, 2002). Secara umum, koloni karang lunak berbentuk seperti jamur dan lobus (Manuputty, 1996). Distribusi genus Sarcophyton ini terbatas pada daerah kedalaman 1 hingga $35 \mathrm{~m}$ di seluruh perairan Indo-Pasifik (Benayahu, 1985; McFadden et al., 2006). Karang lunak berkembang biak dengan cara gonochoric. Larva Sarcophyton sp. yang dihasilkan dari reproduksi gonochoric mampu bertahan 14 hari dalam kolom air (Benayahu dan Loya, 1986). Perkembangbiakan aseksualnya berlangsung secara fragmentasi (Fabricus \& Philip, 2001).

Karang lunak biasa dijadikan sebagai karang hias karena bentuk dan corak warnanya yang menarik. Genus Sarcophyton ini telah dieskpor ke berbagai negara di dunia (Green \& Shirley, 1999). Harga jual karang lunak untuk keperluan ekspor cukup tinggi, sekitar \$300-an per box (http://www.livestockusa.org/). Menurut Green \& Shirley (1999), berdasarkan data Convention on International Trade in Endangered Species of Wild Fauna and Flora (CITES) 1985-1997, Indonesia merupakan negara pengekspor karang hias terbesar di dunia, jumlahnya sekitar $41 \%$ dari jumlah total karang hias yang diekspor ke Amerika, Hongkong, Jepang dan negara-negara di Eropa. Namun, tingginya permintaan karang lunak ini tidak seimbang dengan keberadaannya yang sedikit di ekosistem terumbu karang, karena saat ini telah terjadi degradasi ekosistem terumbu karang yang salah satunya disebabkan oleh adanya aktivitas manusia (Spalding et al., 2001). Wilkinson (2002) menjelaskan bahwa ekosistem terumbu karang mengalami degradasi sebesar $10-50 \%$ selama kurun waktu 50 tahun terakhir. Pemanasan global juga dapat mempercepat laju kerusakan ekosistem terumbu karang sebagai habitat (Hoegh-Guldberg, 2011).

Perubahan kondisi lingkungan tersebut dapat menyebabkan perubahan komposisi spesies dalam suatu ekosistem, sedangkan dampak perubahan komposisi spesies dapat menurunkan keragaman genetik pada suatu populasi. Menurut Ambariyanto (2010) kondisi sumber daya hayati laut yang rusak akan berdampak pada banyaknya organisme laut yang menuju kepunahan.

Keragaman genetik merupakan suatu variasi di dalam populasi yang terjadi akibat adanya keragaman di antara individu yang menjadi anggota populasi. Genetik dapat dijadikan kunci konservasi karena berperan penting dalam mempertahankan populasi dan pemulihan dari kerusakan. Oleh karena itu, informasi mengenai keragaman genetik membantu dalam proses pengelolaan kawasan perlindungan laut secara berkelanjutan. Karakteristik geografis dan lingkungan yang berbeda-beda antara Pulau Jawa, Sulawesi dan Nusa Tenggara akan membuat perbedaan-perbedaan pada keragaman genetik. Oleh karena itu, penelitian ini penting untuk mengetahui keragaman genetik $S$. 
trocheliophorum yang diharapkan dapat membantu upaya pengelolaan konservasi sebagai wujud perlindungan keanekaragaman hayati Indonesia.

\section{METODOLOGI}

\section{Pengambilan Sampel}

Pengambilan sampel karang lunak dilakukan di Jawa (Pulau Tunda dan Pulau Seribu), Nusa Tenggara (Labuan Bajo dan Gili Tapan) dan Sulawesi (Pulau Sembilan, Pulau Tanakeke dan Pulau Dutungan) (Gambar 1). Analisis molekuler dilakukan di Laboratorium Biosistematika dan Biodiversitas Kelautan, IImu Kelautan, Institut Pertanian Bogor. Sampel dikoleksi dengan menggunakan alat SCUBA/snorkel, pada kedalaman 5-7 m. Pengambilan sampel dilakukan secara non-destruktif, yaitu dengan mengambil semua sampel yang ditemukan tanpa merusak organisme tersebut. Pengambilan jaringan karang dilakukan secara acak sepanjang $3 \mathrm{~cm}$. Jaringan kemudian dibilas dengan air tawar untuk menghilangkan zooxanthellae yang menempel, lalu diawetkan dalam ethanol $96 \%$.

\section{Analisis Karakteristik Molekuler}

Ekstraksi DNA dilakukan dengan menggunakan extraction kit (Qiagen). Proses ekstraksi DNA diawali dengan pencucian jaringan dengan menggunakan aquades untuk menghilangkan pengaruh etanol. Selanjutnya dilakukan penggerusan jaringan dengan menggunakan microsmash untuk mempermudah proses lisis jaringan dalam tahap inkubasi. Jaringan yang telah halus direasikan dengan reagen dari kit Qiagen lalu diinkubasi pada suhu $56^{\circ} \mathrm{C}$ hingga jaringan hancur. Pemisahan DNA dilakukan dengan menggunakan centrifuge pada kecepatan $13.000 \mathrm{rpm}$.

DNA yang dihasilkan dari proses ekstraksi, diamplifikasi dengan menggunakan urutan primer 16S647F: 5'-ACACAGCTCGGTTTCTATCTACCA-3' dan ND21418R: 5'- ACATCGGGAGCC CACATA-3'untuk fragmen ND2. (Sanchez et al., 2003). Primer ini mengamplifikasi DNA pada bagian mitokondria. Sebanyak $3 \mu$ INA direaksikan dengan 12,5 $\mu$ Q Q5 high fidelity master mix, $7 \mu \mathrm{l}$ $\mathrm{ddH}_{2} \mathrm{O}$, primer forward dan reverse masing-masing $1,25 \mu \mathrm{l}$ dengan total campuran $25 \mu \mathrm{l}$. Amplifikasi dilakukan dengan urutan pre-denaturation pada suhu $98^{\circ} \mathrm{C}$ selama 30 detik, denaturation pada suhu $98^{\circ} \mathrm{C}$ selama 30 detik, annealing pada suhu $57{ }^{\circ} \mathrm{C}$ selama 30 detik dan extension pada suhu $72{ }^{\circ} \mathrm{C}$ selama 30 serta final extention pada suhu $72{ }^{\circ} \mathrm{C}$ selama 2 menit dalam 35 siklus.

Elektroforesis dilakukan pada gel agarosa 1,5\% dengan pewarna Etidium Bromidea $(4 \mu \mathrm{l})$ dan larutan TAE 1 X $100 \mathrm{ml}$. Hasil PCR sebanyak $4 \mu \mathrm{l}$ yang telah ditambahkan dengan loading dye $(1 \mu \mathrm{l})$, dimasukkan ke dalam sumur agarosa. Setelah itu dielektroforesis pada tegangan $100 \mathrm{~V}$ selama 25 menit. Pita hasil elektroforesis dilihat dengan menggunakan sinar ultraviolet pada UV transillluminator. Hasil PCR yang positif mengandung DNA yang diinginkan, dikirim ke Barkley, USA untuk dilakukan sekuensing.

\section{Keanekaragaman Genetik}

\section{Analisis Data}

Hasil sekuensing yang didapat diurutkan dengan menggunakan program Clustal W dari software MEGA 5.05 (Moleculer Evolutionary Genetic Analysis) (Tamura et al., 2011). Sekuen DNA yang didapat dibandingkan dengan sekuen DNA pada basis data (GenBank) untuk memastikan spesies tersebut ialah $S$. trocheliophorum. Software DNAsp 5.0 (Rozas et al., 2003) digunakan untuk mengetahui keanekaragaman haplotype $\left(H_{d}\right)$ (Nei, 1987) dan keanekaragaman nukleotida $(\pi)$ (Lynch \& Crease, 1990) pada masing-masing populasi. 


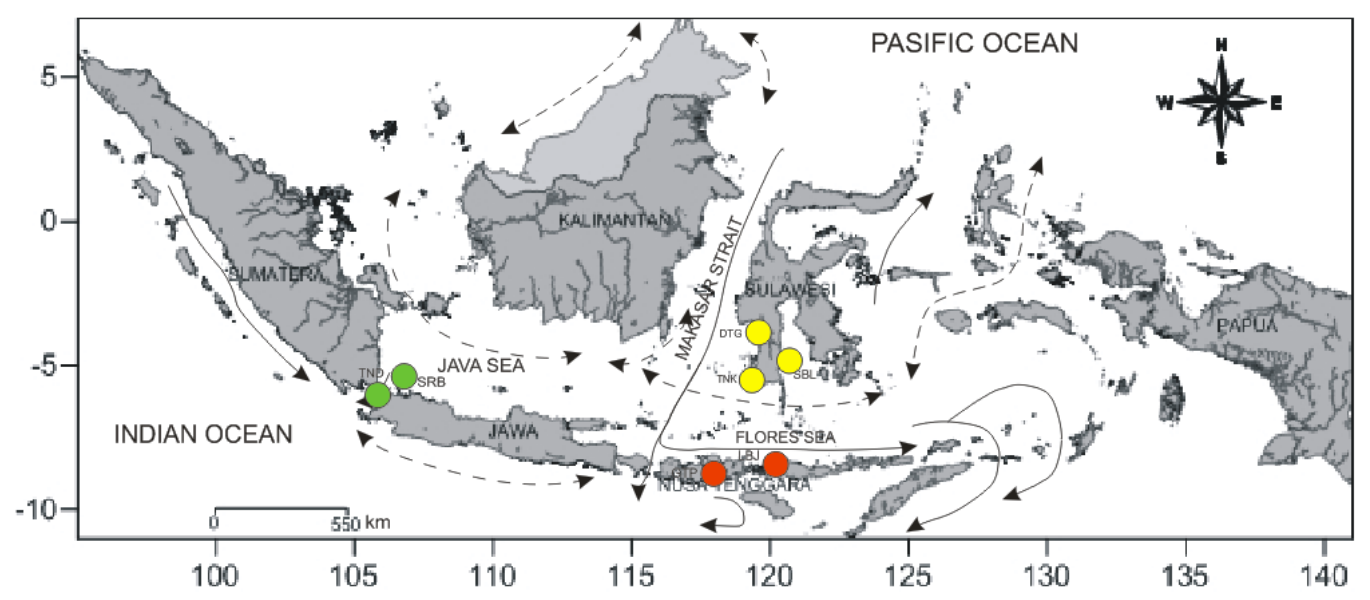

Gambar 1. Peta Pengambilan Sampel S. trocheliophorum di Populasi Jawa (Hijau), Nusa Tenggara (Merah), Sulawesi (Kuning).

\section{HASIL DAN PEMBAHASAN}

\section{Keragaman Genetik}

Hasil penelitian menunjukkan panjang fragmen DNA dari sampel yang didapat yaitu 750 bp (Gambar 1), dengan tingkat kesamaan $99-100 \%$ dengan Sarcophyton trocheliophorum pada GenBank. Dari 39 sampel yang dianalisis pada program DNAsp didapatkan 21 haplotype (Tabel 1). Populasi Jawa dengan 6 sampel memiliki haplotype sebanyak 3 buah. Pada populasi Sulawesi ditemukan 11 haplotype dari 24 sampel, sedangkan pada populasi Nusa Tenggara didapat 8 haplotype dari 9 sampel. Keragaman genetik pada tiap populasi memiliki tingkat keragaman haplotype yang tinggi, yaitu berkisar 0,600 0,972 (Nei, 1987). Keragaman haplotype terendah terdapat pada populasi Jawa, sedangkan keragaman tertinggi terdapat pada populasi Nusa Tenggara 0.972. Keragaman nukleotida berkisar antara 0,002 sampai dengan 0,019, dengan nilai terendah yaitu pada populasi Jawa dan tertinggi pada populasi Sulawesi. Secara kesuluruhan, keragaman haplotype yaitu sebesar 0,914 dan keragaman nukleotida sebesar 0,028. Menurut Nei (1987) nilai keragaman genetik yang berkisar 0,8 - 1 masuk dalam kategori tinggi, sementara nilai 0,5 - 0,7 tergolong dalam kategori sedang dan 0,1-0,4 merupakan kategori rendah.

Tabel 1 . Total haplotype $\left(H_{n}\right)$, haplotype diversity $\left(H_{d}\right)$, nucleotide diversity $(\pi)$ and total samples ( $\mathrm{n}$ ) of in Java, Sulawesi dan Nusa Tenggara population.

\begin{tabular}{lcccc}
\hline \multirow{2}{*}{ Population } & $n$ & \multicolumn{3}{c}{ Genetic Diversity } \\
\cline { 3 - 5 } \cline { 3 - 5 } & & $H_{n}$ & $H_{d}$ & $\pi$ \\
\hline Java & 6 & 3 & 0.6 & 0.002 \\
Sulawesi & 24 & 11 & 0.815 & 0.019 \\
Nusa Tenggara & 9 & 8 & 0.972 & 0.019 \\
Total Populasi & 39 & 21 & 0.914 & 0.028 \\
\hline
\end{tabular}


Rendahnya keragaman genetik yang terdapat pada populasi Jawa $(0,600)$ ukuran populasi yang rendah di lokasi tersebut Nuryanto (2009) menyebutkan bahwa keragaman genetik yang tinggi mencerminkan besarnya ukuran populasi, sehingga penurunan ukuran populasi akan mengurangi keragaman genetik. Ukuran populasi di Jawa memang sangat kecil, hal ini dari jumlah data yang rendah. Nilai keragaman genetik yang kecil pada populasi Jawa diduga disebabkan karena perairan Laut Jawa banyak mengandung limbah domestik dan pabrik yang berasal dari Teluk Jakarta (Sachoemar \& Wahjono, 2007), sehingga mengganggu pertumbuhan yang berdampak pada kematian. Jawa mempunyai keragaman genetik yang lebih rendah dibandingkan dengan populasi lain, walaupun menurut Nei (1987) populasi ini masih masuk dalam kategori yang tinggi. Keragaman genetik pada populasi Jawa berbanding terbalik dengan populasi Nusa Tenggara dan populasi Sulawesi, (masing-masing 0,972 dan $0,815)$. Besarnya keragaman genetik ini diduga karena tingginya ukuran populasi di dua tempat tersebut. Nusa Tenggara dan Sulawesi menurut data kualitas lingkungan hidup memiliki perairan yang belum banyak menerima bahan pencemar dibandingkan Jawa (KLH, 2011).

Selain pencemaran lingkungan, penangkapan berlebih yang terjadi di wilayah pesisir laut juga berdampak terhadap penurunan keragaman genetik pada suatu populasi. Penangkapan ikan dengan menggunakan bom maupun racun sianida juga memengaruhi komunitas terumbu karang. Pariwisata yang tidak ramah lingkungan turut menyumbang tekanan terhadap ekosistem terumbu karang, sehingga menyebabkan kerusakan. Menurunnnya ukuran populasi yang menyebabkan keragaman genetik rendah dimungkinkan juga karena pengaruh kenaikan suhu permukaan air yang berdampak pada simbion, sehingga terjadi pemutihan. Hilangnya zooxanthellae akan mempengaruhi pertumbuhan. Sarcophyton sp. merupakan karang lunak yang hampir separuh keperluan nutrisiya diperoleh dari zooxanthellae. Genus ini akan stres pada suhu $39{ }^{\circ} \mathrm{C}$ jika terpapar panas lebih dari 39 jam (Strychar et al., 2005). Hal ini yang mungkin terjadi pada populasi S. trocheliophorum di Populasi Jawa.

\section{Implikasi Terhadap Kawasan Konservasi Laut}

Rendahnya tingkat keanekaragaman haplotype (Tabel 1) yang terjadi pada populasi $S$ - di Pulau Jawa menandakan kecilnya ukuran populasi ini dibandingkan dengan populasi lainnya, walaupun sebenarnya ketiga populasi ini masih masuk dalam kategori tinggi menurut Nei (1987), sehingga dimungkinkan banyak dari jenis ini yang melakukan inbreeding (perkawinan sedarah). Inbreeding berbahaya bagi suatu populasi karena dapat menurunkan keragaman genetik suatu populasi (Valtuena et al, 2014). Akan tetapi, pengujian terhadap efek negatif inbreeding menggunakan analisis parental dengan menggunakan DNA inti belum dilakukan pada penelitian ini untuk membuktikannya.

Keragaman genetik suatu spesies memberikan kemampuan untuk beradaptasi terhadap perubahan lingkungan dan iklim serta penyakit. Oleh karena itu, keragaman genetik merupakan modal dasar bagi untuk tumbuh, berkembang dan beregenerasi. Kemampuan karang untuk beradaptasi dengan perubahan lingkungan yang terjadi ditentukan oleh potensi keragaman genetik yang dimilikinya. Semakin tinggi keragaman genetiknya, semakin besar peluang untuk beradaptasi dengan lingkungan (Perwati, 2009). Oleh karena itu, perlu adanya pembentukan kawasan konservasi laut yang menyeluruh dan terpadu. Mengingat potensi sebagai karang hias dan bahan ekspor.

Pembentukan kawasan konservasi laut di Indonesia diatur pada Keppres nomor 32 tahun 1990 yang menyebutkan bahwa kawasan konservasi terdiri atas; (i) kawasan yang memberikan perlindungan kawasan bawah (hutan lindung, 
bergambut, resapan air); (ii) kawasan perlindungan setempat (sempadan pantai, sungai, sekitar danau atau waduk, mata air); (iii) kawasan suaka alam dan cagar budaya (suaka alam, hutan bakau, taman nasional, cagar budaya dan ilmu pengetahuan). Hal ini bahwa saat ini proses pembentukan daerah konservasi hanya berdasarkan daerah kawasan, sedangkan pembentukan daerah konservasi laut yang melibatkan kawasan masih sangat kurang. Genetik yang terjaga baik dapat meningkatkan keragaman genetik. Hal ini dapat terjadi karena lancarnya transfer genetik yang berada di antara kedua populasi jenis yang bersilang.

Kecilnya keragaman genetik di populasi Jawa (Tabel 1) memerlukan perhatian khusus agar tetap terjaga kelestariannya, sehingga tidak terjadi kepunahan lokal. Oleh karena itu, perlu dilakukan pembentukan kawasan perlindungan laut yang ketat. Hal ini sesuai dengan pernyataan Bengen (2002) bahwa salah satu upaya perlindungan ekosistem pesisir dan laut adalah dengan menetapkan suatu kawasan laut sebagai kawasan konservasi. Pembentukan kawasan konservasi bertujuan untuk melindungi habitat yang kritis, mempertahankan dan meningkatkan kualitas, melindungi keanekaragaman hayati dan melindungi proses-proses ekologi.

\section{KESIMPULAN DAN SARAN}

Keragaman genetik populasi Sulawesi dan Nusa Tenggara tergolong tinggi, sedangkan populasi Jawa masuk dalam kategori sedang. Kecilnya keragaman genetik pada populasi Jawa dimungkinkan karena berkurangnya ukuran populasi $S$. trocheliophorum yang diakibatkan karena kerusakan lingkungan di Pulau Jawa.

\section{UCAPAN TERIMAKASIH}

Penulis mengucapkan terima kasih kepada badan pendidikan tinggi (DIKTI) yang telah memberikan dana penelitian. Beginer Subhan, Dondy Arafat, Seluruh staf Laboratorium Biosistematika dan Biodiversitas Kelautan FPIK IPB serta rekan-rekan yang telah membantu jalannya penelitian ini.

\section{DAFTAR PUSTAKA}

Ambariyanto. 2010. Kebijakan pengelolaan organisme laut dilindungi: kasus Kerang Raksasa. Pidato pengukuhan Guru Besar Ilmu Kelautan pada Fakultas Perikanan dan Ilmu Kelautan, UNDIP.

Bandelt, H.J, P. Forster \& A. Röhl. 1999. Median-joining networks for inferring intraspecific phylogenies. Mol Biol Evol, 16: 37-48.

Benayahu, Y \& Y. Loya. 1986. Sexual reproduction of a soft coral: Synchronous and brief annual spawning of Sarcophyton glaucum (Quoy \& Gairmard. 1833). Biol. Bull., 170: 32-42.

Benayahu, Y. 1985. Faunistic compotition and pattern in the distribution of softcoral (Octocorallia Alcyonacea) along the coral reefs of Sinai Peninsula. Proc. 5th Int. Coral Reef Symp. Tahiti, 6:255-260.

Bengen, D.G. 2002. Sinopsis ekosistem sumberdaya alam pesisir dan laut serta prinsip pengelolaannya. Bogor. Pusat Kajian Sumberdaya Pesisir dan Lautan. Institut Pertanian Bogor. 66 hal

Botsford, L.W, J.W. White, M.A. Coffroth, C.B. Paris, S. Planes, T.L. Shearer, S.R. Thorrold, \& G.P. Jones. 2009. Connectivity and resilience of coral reef metapopulations in marine protected areas: matching empirical efforts to predictive needs. Coral Reefs, 28: 327-337. 
Excoffier, L \& H. Lischer. 2009. Arlequin ver 3.5 User Manual; An Integrated Software Package For Population Genetics Data Analysis. Swiss Institute of Bioinformatics. Switzerland. $174 \mathrm{pp}$

Exoffier, L, P.E. Smouse \& J.M. Quattro. 1992. Analysis of moleculer variance inferred from metric distance among DNA haplotypes; application to human mitochondrial DNA restriction data. Genetics, $131: 479-491$.

Fabricus, K \& A. Philips. 2001. Softcoral and Sea fans. Australia. Australia Institute Of Marine Science.

Gordon, A.L \& R.A Fine. 1996. Pathways of water between the Pacific and Indian Oceans in the Indonesian seas. Nature, $379: 146-149$.

Green, E.R \& F. Shirley. 1999. The Global Trade in Coral. World Conservation Monitoring Centre. World Conservation Press, Cambridge, UK.60 pp.

Hellberg, M.E, R.S. Burton, J.E. Neigel \& S.R. Palumbi. 2002. Genetic assessment of connectivity among marine population. Bulletin of Marine Science, 70(1): 273-290.

Hoegh-Guldberg, O. 2011. Coral reef ecosystems and anthropogenic climate change. Reg Environ Change, 11:215-227.

Jackson, J.B.C. 1986. Modes of dispersal of clonal benthic invertebrates: consequences for species' distribution sand genetic structure of local populations. Bull Mar Sci., 32: 588-606.

Kementerian Lingkungan Hidup. 2011. Laporan Indeks Kualitas Lingkungan Hidup Indonesia. 1-70 pp

Lynch, M \& T.J. Crease. 1990. The analysis of population survey data on DNA sequence variation. Moleculer Biology Evolution, 7: 337-394.

Manuputty, A.E.W. 2002. Karang lunak (soft coral) Perairan Indonesia dalam: Buku I, Laut Jawa \& Selat Sunda. Pusat Penelitian Oseanografi. LIPI. Jakarta. $91 \mathrm{hlm}$

Manuputty, A.E.W. 1996. Pengenalan beberapa karang lunak (Octocorallia, Alcyonacea) di lapangan. Oseana, 21(4): 1-11.

McFadden, C.S, P. Alderslade, L.P. van Ofwegen, H. Johnsen \& A. Rusmevichientong. 2006. Phylogenetic relationships within the tropical soft coral genera Sarcophyton and Lobophytum (Anthozoa, Octocorallia). Invertebrate Biology, 125(4):288-305.

Munday, P.L, J.M. Leis, J.M. Lough, C.B. Paris, M.J. Kingsford, M.L. Berumen \& J. Lambrechts. 2009. Climate change and coral reef connectivity. Coral Reefs, 28: 379-395.

Nei, M. 1972. Genetic distance between population. American Nature, 106: 283292.

Nei, M. 1978. Estimation of average heterozygosity and geneti distance from a small number of individuals. Genetics, 89: 583-590.

Nei, M. 1987. Moleculer Evolutionary Genetics. New York. Columbia University. Press. New York. $512 \mathrm{pp}$

Nuryanto, A \& M. Kochzius. 2009. Highly restricted gene flow and deep evolutionary lineages in the giant clam Tridacna maxima. Coral Reefs, 28: 607-619.

Perwati, L.K. 2009. Analisis derajat ploidi dan pengaruhnya terhadap variasi ukuran stomata dan spora pada Adiantum raddianum. Bioma, 11(2): 3944.

Rozas, J, B.J.C. Sanchez-Del, Messeguer \& X.R. Rozas. 2003. DnaSP, DNA polymorphism analyses by the coalescent and other methods. Bioinformatics, 19: 2496-2497.

Sachoemar, S.I \& H.D. Wahjono. 2007. Pencemaran lingkungan perairan di Teluk Jakarta. JAI., 3(1): 1-14. 
Sa'nchez, J.A, C.S. McFadden, S.C. France \& H.R. Lasker HR. 2003. Molecular phylogenetic analyses of shallow-water Caribbean octocorals. Mar. Biol. 142: 975-987.

Spalding, M.D, C. Ravilious, E.P Green. 2001. World atlas of coral reefs. UNEP World Conservation Monitoring Centre, University of California Press, Berkeley. 424 pp

Strychar, K.B, T.M. Coates, P.W. Sammarco, T.J. Piva \& P.T. Scott. 2005. Loss of Symbiodinium from bleached soft corals Sarcophyton ehrenbergi, Sinularia sp. and Xenia sp. Journal of Experimental Marine Biology and Ecology, 320: 159-177.

Tamura K, Peterson D, Peterson N, Stecher G, Nei M, Kumar S. 2011. MEGA5: Molecular evolutionary genetics analysis using maximum likehood, evolutionary distance and maximum parsimony method. Moleculer Biology Evolution, 28(10): 2731-2739.

Valtuena, F.J, J. Lopez, A.O. Olivencia, T.R. Riano \& M. Gonzales. 2014. Contrasting inbreeding depression in early and late stages of the life cycle of a Mediterranean shrub, Anagyris foetida (Leguminosae). Turkish Journal of Botany, 38: 334-346

Wijayanti, D.P, E. Indrayanti \& C.A. Suryono. 2009. Kajian Konektivitas Genetik Antar Terumbu Sebagai Dasar Perencanaan Kawasan Restorasi Karang Dalam Upaya Menghadapi Global Warming. Semarang:Universitas Diponegoro. $30 \mathrm{pp}$

Wilkinson, C. 2002. Status of coral reefs of the world:2002. Australian Institute of Marine Science. $363 \mathrm{pp}$ 